\title{
Ethics of Scientific Research
}

\section{Ragab Abou Melih Mohamed Soliman}

To Link this Article: http://dx.doi.org/10.6007/IJARBSS/v11-i12/11922

DOI:10.6007/IJARBSS/v11-i12/11922

Received: 17 October 2021, Revised: 22 November 2021, Accepted: 06 December 2021

Published Online: 25 December 2021

In-Text Citation: (Soliman, 2021)

To Cite this Article: Soliman, R. A. M. M. (2021). Ethics of Scientific Research. International Journal of Academic Research in Business and Social Sciences, 11(12), 1980-1986.

\section{Copyright: (C) 2021 The Author(s)}

Published by Human Resource Management Academic Research Society (www.hrmars.com)

This article is published under the Creative Commons Attribution (CC BY 4.0) license. Anyone may reproduce, distribute, translate and create derivative works of this article (for both commercial and non0-commercial purposes), subject to full attribution to the original publication and authors. The full terms of this license may be seen at: http://creativecommons.org/licences/by/4.0/legalcode

\section{Vol. 11, No. 12, 2021, Pg. $1980-1986$}

Full Terms \& Conditions of access and use can be found at http://hrmars.com/index.php/pages/detail/publication-ethics 


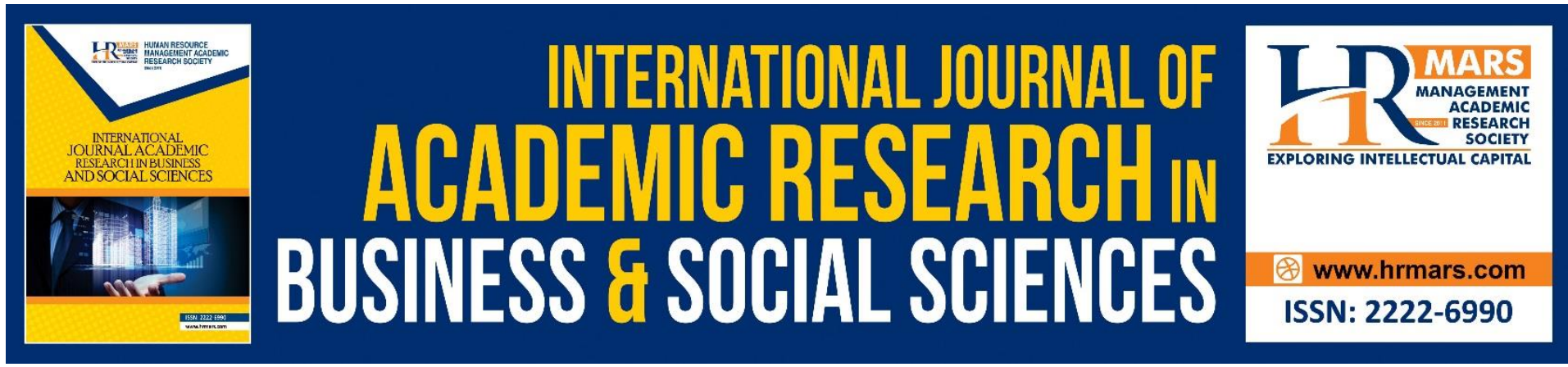

\title{
Ethics of Scientific Research
}

\author{
Ragab Abou Melih Mohamed Soliman \\ Associate Professor, Kulliyyah of Shariah and Law, Universiti Islam Antarabangsa Sultan \\ Abdul Halim Mu'adzam Shah (UniSHAMS), 09300, Kuala Ketil, Kedah. \\ Email: drragab@unishams.edu.my
}

\begin{abstract}
This paper deals with the ethics of scientific research. Many research centers focus solely on the fulfilment of the guidelines related to the research form; others are concerned with the research content alone; only a few pays attention to the ethics of scientific research despite their paramount importance. Without ethics, scientific research turns into a curse that hits the individual, the society and the whole nation. On the other hand, commitment to ethics makes scientific research a constructive agent that serves humanity and yields ripe fruits in the religious, economic, social, political and various other aspects. That is the topic that this paper attempts to elaborate on.
\end{abstract}

\section{Introduction}

Praise be to God, and prayers and peace be upon the Messenger of God, may God's prayers and peace be upon him. Then, after many of those research and books that dealt with scientific research in all its scientific and skill aspects, until it came to some writers or postgraduate centres obligating students to a number of words on one page, font type, margin space, space between lines, cover colour, and what to write on it, to other details that hinder scientific research, and waste the essence for the sake of appearance.

A few of these researches dealt with the ethical and behavioural aspect of researchers in the scientific field in general and the legal field in particular. In these few pages, I will try to point out some of these morals, etiquette, and behaviour, which I believe will benefit the researcher in general and the researcher in the legal field in particular.

\section{Research Objectives}

Through this research, the researcher aims to reach several goals, the most important of which are:

1- Highlighting the importance of the ethical side and its positive impact on scientific research.

2- Emphasis on behavioural controls and their impact on scientific research.

3- Seeking to find a charter or constitution that governs and controls scientific research that deals with the ethics and morals that the researcher must possess, especially the researcher in the legal aspects.

4- Access to the attributes of the divine scientist who benefits from the legal sciences and uses them to serve himself, his society and his nation. 


\section{Research Methodology}

The researcher tried to use the descriptive and inductive method in describing the problem under study, then the scientific method in terms of collecting and criticizing the scientific material and then arriving at the results that are extracted from the introductions. The researcher sought to document texts from their approved sources, write verses in Ottoman drawing, and extract hadiths from approved Sunnah books.

\section{Research Problem}

The research problem revolves around the subject of scientific research and the ethical problems that negatively affect the researcher. And then transmitted from him to his students and those who learn on his hands.

\section{Research Questions}

Through this research, the researcher tries to answer these questions.

1- What are the manners and morals that a researcher in general and a researcher in legal matters in particular must possess?

2- What are the consequences of adopting these manners and morals?

3- How can we employ these ethics and morals to advance scientific research and benefit fully and seriously from it at the level of the individual, family and society?

This research paper has been divided into a preface and several research points:

- In the introduction I talked about what is meant by ethics, and what is meant by scientific research.

1- Sincerity and correct intention in seeking knowledge and teaching it.

2- Fear of God Almighty.

3- Work with knowledge as much as possible.

4- The literature of jurisprudence.

5- impartiality and objectivity.

6- Academic honesty and taking into account the rights of others when benefiting from them. The preamble deals with what is meant by creation, and what is meant by scientific research. First: What is meant by creation: Creation: is a well-established form of the soul from which actions are issued easily and smoothly, without the need for thought and deliberation. If the appearance is such that beautiful actions come from it in a rational and legal manner easily, then the appearance is called good character, and if the ugly actions result from it, the appearance that is the source is called bad character. Rather, we said that it is a wellestablished body, because whoever is issued from him spends money on the doors in an accidental case, his character is not said to be generous unless he proves that in himself. Likewise, he who is obligated to remain silent when angry, with effort and deliberation, is not said to have been created by a dream. Creation is not an act, for perhaps a person is created by generosity and does not exert himself, either for the loss of money or for an impediment, and perhaps his character is miserliness while he is doing for a reason or hypocrisy. Definitions from Al-Jurjani p. 113.

Islam is a message of values and morals in the first place, until the Prophet - may God's prayers and peace be upon him - was reported to have said:

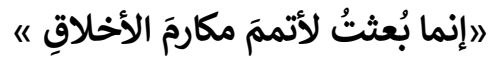

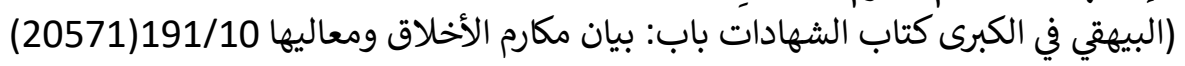


(Al-Bayhaqi in Al-Kubra, Book of Testimonies, Chapter: Explanation of Honourable Ethics and Their Excellences 10/191 (20571).

Second: Scientific Research: Definitions of scientific research as an additional compound abounded, so some of them defined it as a study in a specific subject according to certain methods and principles (Abu Suleiman Abdel-Wahhab Ibrahim 21).

\section{1- Sincerity and correct intention in seeking knowledge and teaching it}

Sincerity is one of the actions of the heart, rather it is at the forefront of the heart's actions, because the acceptance of actions cannot be completed without it. What is meant by sincerity is to desire the face of God Almighty with action, and to purify Him from every impurity, personal or worldly. He does not rise to work except for God Almighty and the hereafter. His work does not mix with what is tainted by the immediate desires of the soul, apparent or hidden, such as the will of a spoiler, or lust, or position, or money, or fame, or a position in the hearts of people, or seeking their praise, or fleeing from their censure, or pleasing the common people, or a special compliment, or a cure for latent hatred, or a response to hidden envy, or a hidden arrogance, or other ills, whims and impurities, the different ones of which are: the will of anything other than God Almighty to act, whoever he is, and whoever he is.

The basis of sincerity of action: abstracting the "intention" in it to God Almighty. What is meant by intention is the emission of a person's will to achieve a desired goal. The motivating purpose is: the engine of the human will to rush to action. The motivating purposes are many and varied, some of them are material and moral, including the individual and social, and among them are the worldly and the other, and among them are the despicable, the great and the dangerous, including what is desirable, including what is obligatory. Al-Qaradawi Yusuf, intention and sincerity. Page 4

The seeker of knowledge must be patient in his request, seeking reward from God Almighty, and not be stingy in his request with money or effort, as it is stored for him with his Lord, and he will be rewarded with the reward of patient benefactors, on the day the patient will pay their reward without account.

\section{2- Fear of God Almighty}

Fear of God is one of the ripe fruits of knowledge, and one of its beneficial benefits. And knowledge that does not generate fear of God Almighty is knowledge that does not elevate its owner in this world, and does not benefit him in the Hereafter.

God Almighty says:

God Almighty says:

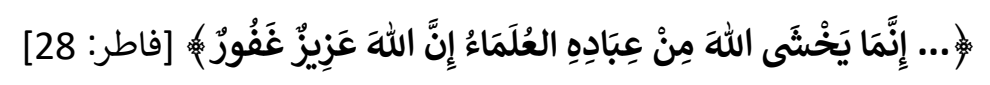

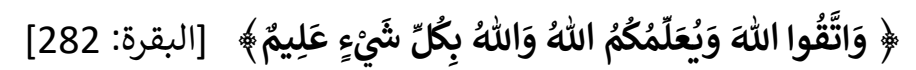

Scholars have abandoned fear and the failure to invoke the sincere intention and sincerity to God, Lord of the Worlds, in his request and exertion, will drag on humanity calamities, and replace its prosperity with misery, and its happiness with misery, its riches with poverty, its security with fear, its dignity and humiliation, and its stability with humiliation and despondency.

The scholar who does not fear God is the one who made the nuclear, bacterial, cluster and chemical bombs that destroyed the crops and offspring and infected the fetuses in the wombs 
of their mothers, and those that were not created, over the lean years, that humanity gained from them nothing but humiliation, shame, misery and poverty.

The scholar who does not fear God is the one who has polluted the entire universe with the remnants of a false civilization that has polluted the air, land and sea, and killed ants in their holes, birds in the liver of the sky, and fish in the depths of the seas.

The scholar who does not fear God is the one who restored the slave market in a brutal and ferocious manner, stole the poor children and cut off their human organs in order to sell them to the rich in the form of kidney, liver, cornea and other transplants.

If fear of God were among the characteristics of scholars, everyone would live in great happiness, not in constant misery.

\section{3- Work with knowledge as much as possible}

Acting without knowledge is one of the calamities from which only the sincere servants of God are spared, and they are few, and then God Almighty warned us against the temptation of the world and his reluctance to act with what he knows and teaches people, as well as his arrogance in doing the right and his disdain for doing wrong.

Allah says in the Quran:

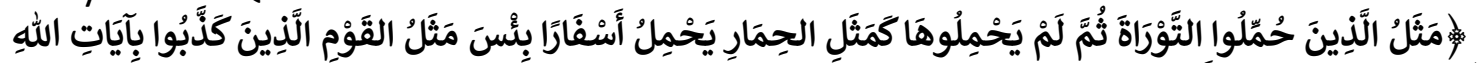

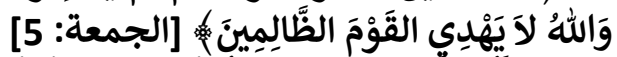

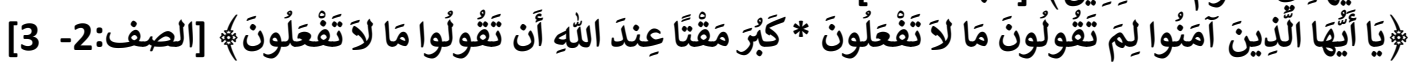

Imam Ali bin Abi Talib, may God be pleased with him, said: "O you bearers of knowledge, act upon it, for the scholar is the one who does what he knows, and his knowledge matches his deeds, and there will be people who will carry knowledge that does not go beyond their throats.

\section{4- The Literature of Jurisprudence}

For many researchers in general and Sharia researchers in particular, the saying "my opinion is right and may be wrong, and the opinion of others is wrong and may be right" and the saying "we cooperate in what we agreed upon and excuse each other in what we differed on" and others. These statements are still theoretical and have not taken their right from practical application. At the first disagreement, even if it is in the branches of the branches, we give free rein to our tongues to delve into our honour, and then we will not cooperate in what we agreed upon, nor what we differed about.

The openness of the heart and the possibility of a dissenting opinion, no matter how weak the point of view of others is, as long as the disagreement in the branches is in the branches is something that the researcher must possess throughout his scientific career, and his journey of learning that will not end until his last breath.

\section{5- Impartiality and Objectivit}

The researcher must be impartial and objective during his discussion of scientific issues, whether they are legal, linguistic or other, and he does not withhold anything from the reader on the pretext that he is not convinced of it, or sees the weakness of his evidence without the spirit of impartiality and objectivity, jurisprudence would have died and disappeared. Perhaps the reader in the book of Al-Mughni by Ibn Qudamah, and its writer is the Hanbali school of thought, or Bidayat Al-Mujtahid by Ibn Rushd, who is the owners of the school, or Al-Majmoo' Sharh Al-Mahdhab by Al-Nawawi, who is, namely Al-Nawawi - the 
Shafi'i school. Before them all, al-Mabsout al-Sarakhsi, who is a follower of Hanafi school, sees verses of beauty, rationality and perfection in presenting the jurisprudential issues of the schools, where the jurist does not stop at the opinion of his school, but rather presents it to everyone and then gives what he wants to outweigh, in a beautiful presentation that indicates impartiality and objectivity, so that these books are classified all in the books of comparative jurisprudence, not doctrinal jurisprudence.

Ibn Rushd took the steps of Fasah during his presentation of the controversy, where the mujtahid at the beginning and the prudent at the end knows the cause and philosophy of the controversy and does not stop at mentioning the dispute alone.

\section{6- Academic Honesty and Taking into Account the rights of others when Benefiting from them.}

Scientific honesty is no less than impartiality and objectivity, as we are the nation of the bond. The researcher has to attribute every opinion to the one who said it, and the blessing of knowledge is its chain of transmission, and the words of contemporary scholars have agreed on this. And the decisions of the respected figh councils, whether they are international or local.

\section{Conclusion and Findings}

First: Ethics is a great importance in the Islamic perspective, as it is one of the fruits of worship and belief in God Almighty.

Second: If morality has this status in Islam, then it is in the field of scientific research in general, and legal research in particular is first, as it protects its owner from error, deception and fraud during research.

Third: Sincerity and correcting the intention in seeking knowledge and giving it is at the top of these morals, as it is one of the actions of the hearts, which if it is good the body is good and the whole work is good, and if it is corrupt the whole work is spoiled.

Fourth: Then comes the fear of God Almighty after sincerity, and it is the creation of this character that puts knowledge in the service of all human beings.

Fifth: From the blessing of knowledge is to act upon it, and whoever works with what he knows, God will grant him knowledge that he did not know, and piety is one of the causes of God's conquests on the Muslim slave.

Sixth: One of the most important etiquettes of scientific research is to be polite with the etiquette of Islam during and after research. Scholars must teach students the etiquette of controversy before they learn the controversy itself.

Seventh: Among the etiquette of scientific research is impartiality, objectivity, and lack of fanaticism for his opinion or doctrine. Rather, he must search for the truth and accept it as long as it is accompanied by evidence.

Eighth: Among the etiquette of scientific research is scientific honesty when transferring from others, and observance of copyright, translation and publishing rights, and all moral rights that have become the subject of agreement between international and local jurisprudence academies and contemporary jurists.

Ninth: There are other etiquettes that it is not possible to mention, including avoidance of emotion, fairness and objectivity. And that he fulfills the conditions for eligibility for scientific research, humility, purposeful criticism, accuracy in communicating from others, honesty, breadth of knowledge, patience, and keeping people's secrets. 


\section{References}

Abu Dawud, S., \& Al-Sijistani, I. H. A. D. S. I. Al-A. (1408-1988). Dar al-Hadith.

Al-Qaradawi, Y. (1995). Daur al-Qayyim wal akhlaq fi al-iqtisad al-islami. 1415 H. Maktabah Wahbah.

Abdul Wahab, I., Abu, S. (1986). Kitabah al-bahthi al-'ilmi wa masadir al-dirasat al-islamiah. 1406 H. Dar al-Syuruq. Jeddah.

Majmu'ah rasail. Imam Hasan al-Banna. Dar al-Tauzi' wa al-nashr al-islamiah. 1412 H. 1992.

Manahij, Al-B. al-'I., \& Al-Shariff, A. M. (1996). Maktabah al-Shi'aa' li al-tiba'ah wa al-nashr wa al-tauzi'. 